EPiC Series in Engineering
Volume 3, 2018, Pages 399-407
HIC 2018. 13th International
Conference on Hydroinformatics

\title{
The knowledge development in flood risk reduction: A case study of Metropolitan Waterworks Authority, Thailand
}

\author{
Udomluck Charoenveangvechakij ${ }^{1}$, Suradet Heramphakun ${ }^{1}$ \\ ${ }^{1}$ Metropolitan Waterworks Authority, Bangkok, Thailand \\ udomluck.c@mwa.co.th, suradet.h@mwa.co.th
}

\begin{abstract}
This paper proposes the knowledge development of the crisis management taking place in the largest drinking water treatment system in Thailand, with the capacity of approximately 4,000,000 CMD. The system encountered with the flood crisis six years ago. Having drawn back to 2011, the flood crisis had massive impact on Metropolitan Waterworks Authority (MWA). For examples, many water treatment processes were disrupted, consumers were not confident on the drinking water quality, and additional operation cost of MWA was raised up about 300 million baht, etc. Therefore, it is an importance to have mitigation measures for the organization to reduce the risk by increasing the capacity of the community and cooperating with the stakeholders to cope with the risks by applying well planned and well-executed in Disaster Risk Reduction (DRR) and Crisis and Emergency Risk Communication (CERC). The result shows the development opportunities of the Metropolitan Waterworks Authority in various aspects from past experiences, and proposes the best practices in order to response with all stakeholders when risks encountered.
\end{abstract}

\section{Introduction}

In 2011, Thailand encountered with the worst flooding in five decades, causing more damage than any other severe weather-related events. The main causes were from many natural storms that hit Thailand in that year and the obvious blockage of drainage system. Consequently, the level of water in waterways was dramatically increased, and flew over the dyke leading to flooding to adjoining areas. Another consequence of the heavy rainfall was the overwhelming amount of water entering and being retained in main dams and Chao Phraya River that reached an overloading capacity. Metropolitan Waterworks Authority (MWA), which is located in the Centre part of Thailand, takes a lot of raw water from Chao Phraya River at Samlae pumping station in Pathumtani to Bangkhen water treatment plant 
in Bangkok with the amount of nearly 4,000,000 CMD through the east raw water canal. Urban floods had large impacts on the water treatment system and both direct and indirect; for examples,

- Operation expenses of MWA flood crisis is about 300 million bath

- Raw water quality was very poor and unsuitable for the limited treatment process

- Contamination in water treatment system

- Many structures of water treatment processes were disrupted

- Prevention systems could not work

- Drinking water could not consume

- Some residences of customers were under the flood

At present, Metropolitan Waterworks Authority has close tie and good collaboration with Royal Irrigation Department for quantity and quality monitoring because climate change makes the weather less predictable, and more likely to have heavy storm rainfalls and to have increased more frequently. In addition, contingency plans should be up-to-date in order to cope with the flood crisis more effectively.

\section{Theory}

\subsection{The Concept of Disaster Risk Reduction}

$$
\text { Risk }=\frac{\text { Hazard } \times \text { Exposure } \times \text { Vulnerability }}{\text { Capacity }}
$$

- Disaster risk is the potential loss of life, injury, or destroyed or damaged assets which could occur to a system, society or a community in a specific period of time, determined probabilistically as a function of hazard, exposure, vulnerability and capacity.

- Hazard is a process, phenomenon or human activity that may cause loss of life, injury or other health impacts, property damage, social and economic disruption or environmental degradation.

- Exposure is the situation of people, infrastructure, housing, production capacities and other tangible human assets located in hazard-prone areas.

- Vulnerability is the conditions determined by physical, social, economic and environmental factors or processes which increase the susceptibility of an individual, a community, assets or systems to the impacts of hazards.

- Capacity is the combination of all the strengths, attributes and resources available within an organization, community or society to manage and reduce disaster risks and strengthen resilience.

From the equation, considering the disaster risk reduction, it does not only take into account the hazard of a disaster. There are three elements; exposure, and vulnerability should decrease and increase the capacity. Capacity is the combination of all the strengths, attributes and resources available within an organization, community or society to manage and reduce disaster risks and strengthen resilience. Therefore, the cooperation of all parties to overcome the crisis together is the way to increase capacity for decrease risk. 


\subsection{Disaster Risk Reduction}

Disaster Risk Reduction into Development was developed by Department of Disaster Prevention and Mitigation subsidising by United Nations Development Programme (UNDP). It showed the concept of risk mitigation and management to the sustainable development. All new development projects should evaluate on all crisis risks namely, flood, earthquake, drought for mitigating directly impacts from the vulnerable crisis. There are five different areas of a development, which addressed; policy, organization, implementation, citizen, and advocacy and knowledge and relative costs and benefits of flood management options as shown in Figure 1 and Figure 2 respectively.

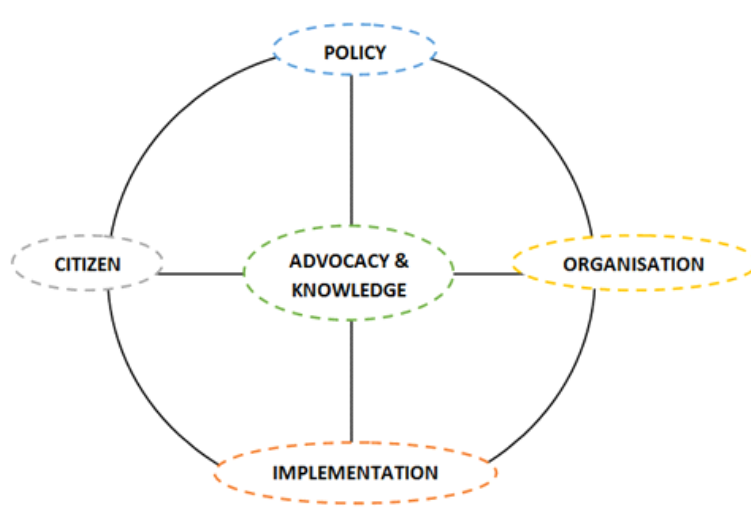

Figure 1: The concept of risk mitigation and management to development

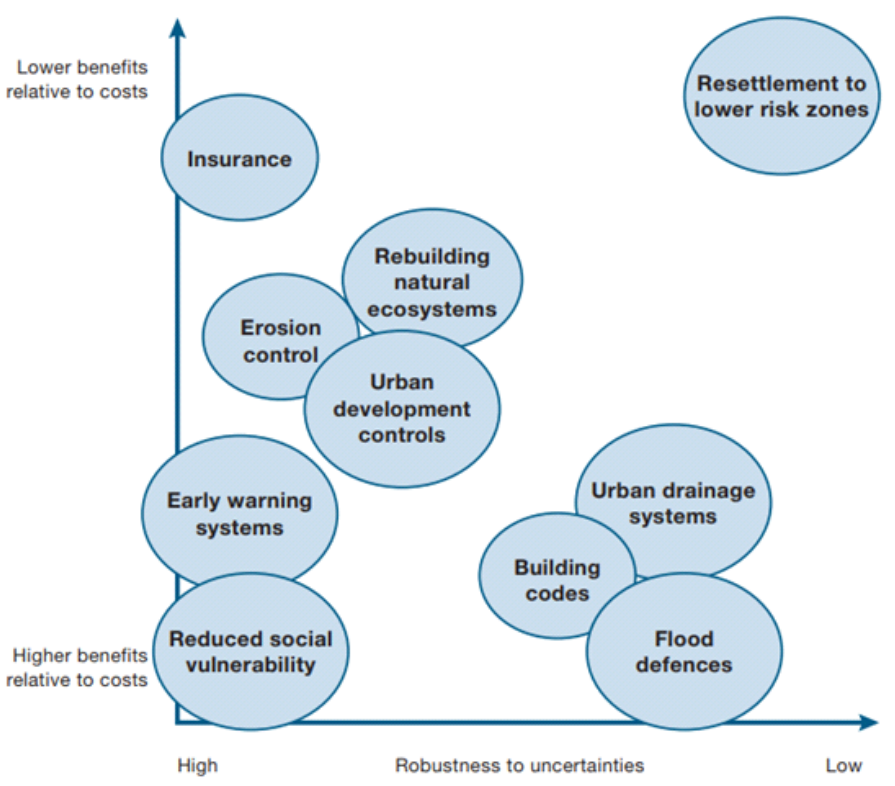

Figure 2: Relative costs and benefits of flood management 
All measures to manage the risks must consider the costs and the benefits, and the acceptable risk in each organization. A measure of reduced social vulnerability can be used in all situations, risk and organization which are based on feelings. It can be used by effective communication of the organisation.

\subsection{Crisis and Emergency Risk Communication}

The principles of crisis and emergency risk communication (CERC) principles tell what to say, when to say it, and how to say it to help you preserve or win the public's trust. More significantly, it can save lives and explain risks and benefits to stakeholders and the public. The principles of risk communication defined each phase in Figure 3

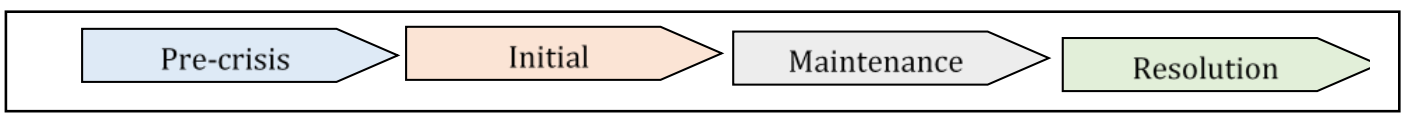

Figure 3: Different stages of crisis

\section{Method}

\subsection{Collect and review the secondary data}

Collected the data from Internal Departments both core and supporting departments such as Water Transmission Canal Department, Bangkhen Water Treatment Plant Department, Water Quality Control Department, Corporate Communication Department, Internal audit, Operation of MWA Department, Monitoring and evaluation department, Risk Management Department. As followed;

- Lesson learned report on the MWA flood crisis 2011

- MWA News release

- Report on the satisfaction of customers after the flood crisis 2011

- Monthly reports on compliant through the MWA branches in the flood crisis 2011 period

- Raw Water Contingency Plan

- Bangkhen Water Treatment Plant Contingency Plan

- Transmission and Distribution Contingency Plan

- Annual report 2011

And collected the data from External Agencies; for example, media, government agency websites.

- Crisis management guideline and many international best practices; as followed,

- Lessons learned from a variety of crisis in many countries

- Newspapers

- Websites 


\subsection{Evaluation and Analysis}

- The conclusion from report on the satisfaction of customers after the flood crisis is shown as in Figure 4

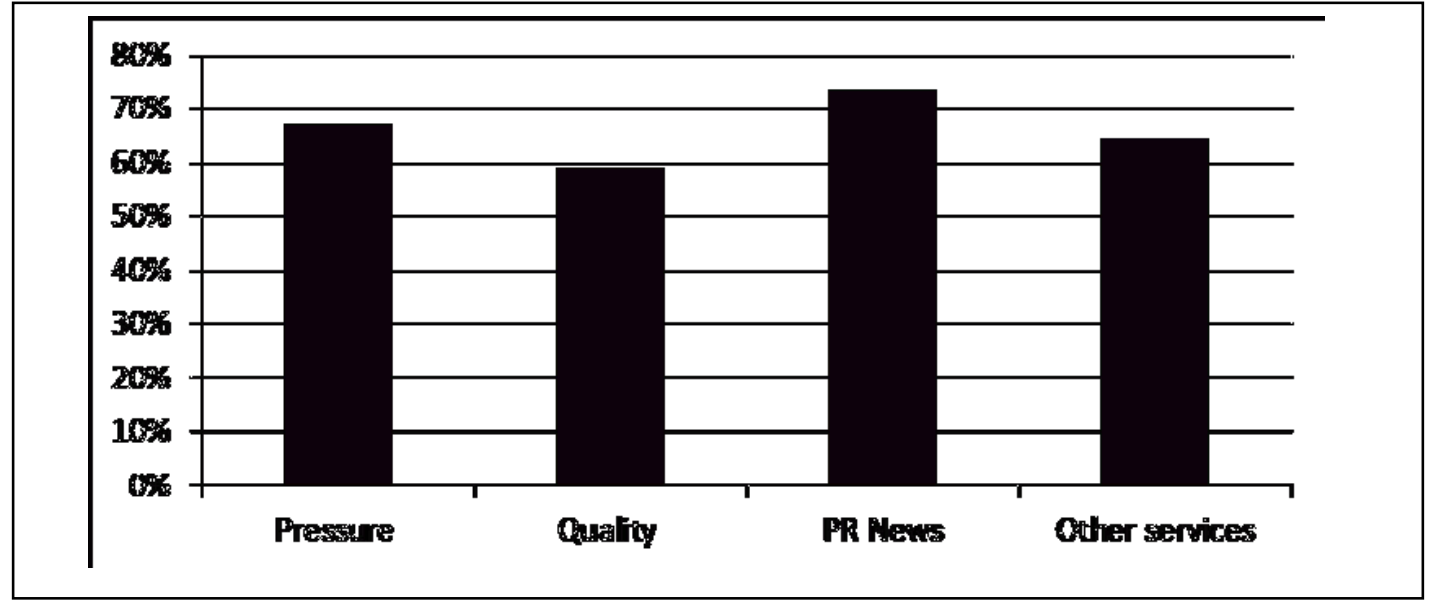

Figure 4: The satisfaction of customers after the flood crisis 2011

After grouping the data, the graph can be displayed as a percentage of satisfaction in 4 groups as follows: PR News, water pressure, other services, and water quality at percentage of 73.8, 67.4, 64.6, and 59.2 respectively. It concluded that the customers are not satisfy with the drinking water quality and are just satisfy with others during the flood.

In addition to the survey, MWA provides the seminar which is focus on the Mass Media Group such as television, radio and print media in order to explore the media's views on the public interest of the Metropolitan Waterworks Authority. It can be concluded that mass media requires the facts from the organization in order to be confident to communicate MWA news to public. In addition, the mass media proposes the organization to provide continuous information. Finally, the organization should provide the name of the person to be interviewed for specific details.

- The major events in MWA flood crisis 2011 are described in Table 1

\begin{tabular}{|c|c|}
\hline No. & Major Events \\
\hline 1 & Flooding of raw water pumping station due to high water levels \\
\hline 2 & $\begin{array}{l}\text { Waste water flow into the canal because the canal is damaged by high } \\
\text { water levels }\end{array}$ \\
\hline 3 & Waste water flow into the canal because the canal is destroyed by people \\
\hline 4 & The water in the canal flows over the canal to flood the houses along the \\
\hline 5 & canal \\
\hline 6 & Reduce the capacity of water production because of the poor water \\
\hline
\end{tabular}

Table 1: Major Events in MWA Flood crisis 2011

- Analyze the development opportunity of a MWA flood crisis management with the practical theories and international best practices

- Analyze MWA news release with CERC principles 


\section{Results}

The results on analysis the data are presented in this section. The results are executed on the data from practical theories; Disaster Risk Reduction (DRR) and Crisis and Emergency Risk Communication (CERC), and the evaluations in Figure 4 and Table 1, MWA news release, newspapers in order to analyze the major events and communication in flood crisis. Metropolitan Waterworks Authority has the following issues and considerations to apply the theories and the evaluations to opportunity development; as followed in Table 2 and Table 3 


\begin{tabular}{|c|c|c|}
\hline & Strength of MWA & Opportunity to development \\
\hline Policy & $\begin{array}{l}\text { - To update emergency plans } \\
\text { like flood, drought crisis }\end{array}$ & $\begin{array}{l}\text { - New construction projects } \\
\text { are taking into account } \\
\text { the disaster } \\
\text { To improve critical } \\
\text { infrastructure to } \\
\text { accommodate disaster } \\
\text { To consider advance } \\
\text { treatment technology into } \\
\text { the conventional aeration } \\
\text { treatment } \\
\text { To construct the barrier } \\
\text { both two sides of the } 31 \\
\text { km-distance canal }\end{array}$ \\
\hline Organization & $\begin{array}{l}\text { To establish an ad hoc crisis } \\
\text { management center } \\
\text { - Working in cross function }\end{array}$ & $\begin{array}{l}\text { To review and improve in } \\
\text { details of MWA crisis } \\
\text { communication plan such } \\
\text { as adding more details, } \\
\text { contact } \\
\text { To insure against damage } \\
\text { in valuable and important } \\
\text { equipment. }\end{array}$ \\
\hline Implementation & $\begin{array}{l}\text { To treat waste water in order } \\
\text { to drinking water, although } \\
\text { production system has } \\
\text { limitation } \\
\text { - To protect the canal from } \\
\text { high water level }\end{array}$ & $\begin{array}{l}\text { To share and show } \\
\text { implementation with the } \\
\text { media } \\
\text { To prepare a step-by-step } \\
\text { to help customers in the } \\
\text { flood }\end{array}$ \\
\hline $\begin{array}{l}\text { Advocacy and } \\
\text { knowledge }\end{array}$ & $\begin{array}{l}\text { To cooperate with } \\
\text { government such as health, } \\
\text { electricity, irrigation, } \\
\text { education organization, etc. } \\
\text { To cooperate with private } \\
\text { sectors like lately install } \\
\text { ozone generator } \\
\text { To make memorandum of } \\
\text { understanding: MOU } \\
\text { To support flood victims by } \\
\text { donate subsidy, drinking } \\
\text { water, } \\
\text { To install the drinking water } \\
\text { taps in the flood areas } \\
\text { To promote the knowledge } \\
\text { management and learning } \\
\text { organization }\end{array}$ & $\begin{array}{l}\text { - } \quad \text { Early warnings about flood } \\
\text { events } \\
\text { - Share information for } \\
\text { warning people in situation } \\
\text { time } \\
\text { - } \quad \text { Asking for help with } \\
\text { stakeholders in advance }\end{array}$ \\
\hline
\end{tabular}

Table 2: The conclusion of MWA disaster risk reduction with opportunity to development 


\begin{tabular}{|c|c|c|}
\hline Steps & Strength of MWA & Opportunity to Development \\
\hline Pre-crisis & $\begin{array}{l}\text { Monitor and recognize emerging risks } \\
\text { Prepare the public for the possibility of } \\
\text { an adverse event } \\
\text { Collaborate and cooperate by developing } \\
\text { alliances with agencies } \\
\text { Develop consensus recommendations by } \\
\text { experts and first responders } \\
\text { Create messages and test them for use in } \\
\text { later stages }\end{array}$ & $\begin{array}{l}\text { Educate the general public about the risks } \\
\text { Increase self-efficacy by suggesting actions } \\
\text { that reduce the likelihood of harm } \\
\text { Provide warning messages regarding an } \\
\text { imminent threat } \\
\text { Build and test communication systems }\end{array}$ \\
\hline Initial & $\begin{array}{l}\text { Designate crisis or agency } \\
\text { spokespersons, and identify formal } \\
\text { channels and methods of communication } \\
\text { Reduce crisis-related uncertainty as } \\
\text { much as possible } \\
\text { Help the public understand the } \\
\text { responsibilities of the various } \\
\text { organizations involved in the response } \\
\text { Promote self-efficacy through personal } \\
\text { response activities, and share how and } \\
\text { where they can get more information }\end{array}$ & $\begin{array}{l}\text { Convey empathy and reassurance. Reduce } \\
\text { emotional turmoil } \\
\text { Establish general and } \\
\text { broad-based understanding } \\
\text { of the crisis circumstances, consequences, and } \\
\text { anticipated outcomes based on available } \\
\text { information } \\
\text { Present information to simple, credible, } \\
\text { accurate, consistent, and delivered on time }\end{array}$ \\
\hline $\begin{array}{l}\text { Maintenan } \\
\text { ce }\end{array}$ & $\begin{array}{l}\text { Encourage broad-based support and } \\
\text { cooperation with response and recovery } \\
\text { efforts } \\
\text { Gather feedback from the affected } \\
\text { public-listen, learn, and assess } \\
\text { Correct misunderstandings, rumor, or } \\
\text { unclear facts } \\
\text { Continue to help people believe they can } \\
\text { take steps to protect themselves }\end{array}$ & $\begin{array}{l}\text { Ensure that the public is updated, understands } \\
\text { on going risks, and knows how to mitigate } \\
\text { risks } \\
\text { Provide background and supportive } \\
\text { information to those who need it } \\
\text { Support informed decision-making by the } \\
\text { public }\end{array}$ \\
\hline Resolution & $\begin{array}{l}\text { Explain on going clean up, remediation, } \\
\text { recovery } \\
\text { Facilitate broad-based, and open } \\
\text { discussion about causes, blame, } \\
\text { responsibility, resolutions } \\
\text { Promote personal preparedness } \\
\text { Promote the activities and capabilities of } \\
\text { organizations by reinforcing positive } \\
\text { identities }\end{array}$ & Improve individual understanding of new risks \\
\hline
\end{tabular}

Table 3: The summary MWA communication with the opportunity to development by using CERC 


\section{Conclusion and Recommendation}

Implementing various theoretical concepts to assess flood management measures within an organization is a key element of the knowledge that will guide process improvement. Risks and measures in flood crisis are identified, all measures can decrease the disaster risks which is the opportunity in development into the MWA flood crisis and management plan. However, helping organization execute MWA mission, maintain public trust, manage limited resources, and limit harm and disruption are crucial, the public wants to know the crucial information during the flood such as the impact of floods on the lives and livelihoods of people, need knowledge and direct communication. Our jobs as public utility and emergency communicators are to offer the information the public needs and counter some of the harmful behaviours during an emergency by well-planned and well-executed communication, fully integrated into the activities of every phase in crisis. Future researchers may evaluate of the benefits and costs of each measure must be integrate with a strategy and combining option. Moreover, the simulation under different scenarios in crisis is the important basic information.

\section{References}

Hydro and Agro Informatics Institute (HAII), Thailand Flood Executive Summary, 2011.

Metropolitan Waterworks Authority (MWA), Flood Crisis Management Plan Report, 2012.

Department of Disaster Prevention and Mitigation, Mainstreaming Disaster Risk Reduction into Development, first ed., Bangkok, 2015.

The World Bank, Cities and Flooding A Guide to Integrated Urban Flood Risk Management for the 21 st Century, 2012.

Barbara Reynolds, Ph.D., Centers for Disease Control and Prevention, Crisis and Emergency Risk Communication, 2014.

Metropolitan Waterworks Authority, MWA News release in flood crisis report, 2011

Metropolitan Waterworks Authority, Report on the satisfaction of customers after the flood crisis, 2012. 